\title{
Positron Emission Tomography Studies of Potential Mechanisms Underlying Phencyclidine-Induced Alterations in Striatal Dopamine
}

\author{
Wynne K Schiffer*, ${ }^{*, 2}$, Jean Logan ${ }^{2}$ and Stephen L Dewey ${ }^{1,2}$ \\ 'SUNY Stony Brook, Department of Neurobiology and Behavior, Stony Brook, NY, USA; ${ }^{2}$ Brookhaven National Laboratory, Chemistry \\ Department, Upton, NY, USA
}

\begin{abstract}
Positron emission tomography (PET), in combination with " 'C-raclopride, was used to examine the effects of phencyclidine (PCP) on dopamine (DA) in the primate striatum. In addition, we explored the hypotheses that GABAergic pathways as well as molecular targets beyond the N-methyl-D-aspartate (NMDA) receptor complex (ie dopamine transporter proteins, DAT) contribute to PCP's effects. In the first series of experiments, ${ }^{~ '}$ C-raclopride was administered at baseline and 30 min following intravenous PCP administration. In the second series of studies, $\gamma$-vinyl GABA (GVG) was used to assess whether enhanced GABAergic tone altered NMDA antagonistinduced changes in DA. Animals received an initial PET scan followed by pretreatment with GVG (300 mg/kg), then PCP $30 \mathrm{~min}$ prior to a second scan. Finally, we explored the possible contributions of DAT blockade to PCP-induced increases in DA. By examining ${ }^{1 /} \mathrm{C}$ cocaine binding a paradigm in which PCP was coadministered with the radiotracer, we assessed the direct competition between these two compounds for the DAT. At $0.1,0.5$, and $1.0 \mathrm{mg} / \mathrm{kg}$, PCP decreased ${ }^{~}{ }^{1} \mathrm{C}$-raclopride binding by $2.1,14.9 \pm 2.2$ and $8.18 \pm 1.1 \%$, respectively. These effects were completely attenuated by GVG $\left(3.38 \pm 3.1 \%\right.$ decrease in ${ }^{~ '}$ C-raclopride binding). Finally, PCP (0.5 mg/ $\mathrm{kg}$ ) decreased " $\mathrm{C}$-cocaine binding by $25.5 \pm 4.3 \%$, while at $1.0 \mathrm{mg} / \mathrm{kg}$ this decrease was $13.5 \%$, consistent with a competitive interaction at the DAT. These results suggest that PCP may be exerting some direct effects through the DAT and that GABA partially modulates NMDA-antagonist-induced increases in striatal DA.

Neuropsychopharmacology (2003) 28, $2192-21$ 98, advance online publication, 23 July 2003; doi: I 0. I038/sj.npp. 1300258
\end{abstract}

Keywords: positron emission tomography (PET); schizophrenia; GABA; phencyclidine; NMDA antagonist; dopamine; vigabatrin

\section{INTRODUCTION}

Phencyclidine (PCP), an N-methyl-D-aspartate (NMDA) receptor antagonist, was developed more than four decades ago as an intravenous anesthetic. Its use was discontinued when it became apparent that it was addictive and frequently produced psychological dependence, compulsive drug-seeking behavior, and profound psychotic episodes. According to the National Household Survey on Drug Abuse (NHSDA), 3.2\% of the population aged 12 years and older have used PCP at least once, and the abuse of its cogener and popular 'club drug', ketamine, has increased dramatically since 1999. While PCP and ketamine are readily self-administered by animals (Rodefer and Carroll, 1999), the role and extent of reward-related dopaminergic processes in these behaviors remain to be established. This becomes even more critical with respect to the similarity

*Correspondence: WK Schiffer, Chemistry Department, Building 555, Brookhaven National Laboratory, Upton, NY I 1973, USA, Tel: + I 63I 344-4395, Fax: + I 63I 344 7902, E-mail: wynne@bnl.gov Received 25 February 2003; revised 22 May 2003; accepted 30 May 2003

Online publication: 5 June 2003 at http://www.acnp.org/citations/ Npp060503030084/default.pdf between PCP-induced psychoses and schizophrenic syndromes that are partially ameliorated by dopamine (DA) antagonist drugs.

Rapid increases in striatal DA appear to represent an integral component of the self-reported 'high', associated with psychostimulants (Volkow et al, 1999). These increases may be achieved directly through interactions with DA releasing or reuptake mechanisms, or indirectly through interactions with other functionally linked neurotransmitter systems. For example, the initial molecular targets of most drugs of abuse, including the opiates, nicotine, and PCP are not dopaminergic. In fact, all these compounds exert their effects through multiple efferent pathways that originate from sites distal to the mesolimbic DA system. With respect to PCP and ketamine, the mechanisms that connect NMDA receptor blockade to striatal DA systems remain undetermined. Some evidence indicates that like the opiates, antagonism of NMDA receptors may prevent the excitation of inhibitory GABAergic neurons that normally modulate these pathways (Grunze et al, 1996; Li et al, 2002). This disinhibition may contribute to the reward-related DA response in the striatum and other mesolimbic and mesocortical brain regions, and may be one mechanism involved in NMDA antagonist-induced psychoses (Olney 
and Farber, 1995). Alternatively, PCP and/or ketamine may stimulate striatal DA through a direct interaction between glutamatergic and dopaminergic neurons (Adams and Moghaddam, 1998). Further complicating possible interactions with DA systems is PCP's relatively potent affinity for the dopamine transporter (DAT) site; an effect not shared by its congener, MK-801 (Johnson and Snell, 1985; Maurice et al, 1991). Nevertheless, since the affinity of PCP for the NMDA receptor is so much greater than its affinity for the $\mathrm{DAT}$, it has been suggested that blockade of transporter proteins is unlikely to contribute significantly to either its behavioral or neurochemical response (Carlezon and Wise, 1996). Moreover, the involvement of DA systems in the rewarding or psychotomimetic properties of PCP has yet to be unequivocally established, and recent studies suggest that NMDA antagonists may exert their effects in the absence of any dopaminergic contribution (Adams et al, 2002; Kegeles et al, 2002).

Therefore, at the most fundamental level, it becomes critical to characterize the dopaminergic response to specific NMDA antagonists. In doing so, novel experimental strategies can begin to unravel the putative mechanisms involved in this response. Positron emission tomography (PET) provides the unique opportunity to observe changes in synaptic DA noninvasively by measuring changes in radiotracer binding. Our laboratory and others have used this technique to provide evidence that ketamine significantly increases synaptic DA transmission (Breier et al, 1998; Smith et al, 1998; Tsukada et al, 2000; Vollenweider et al, 2000). We have also successfully employed this approach to characterize functional interactions between cholinergic, GABAergic, serotonergic, and dopaminergic neurotransmitter systems (Dewey et al, 1990, 1992, 1993a, 1995). In the present study, we used ${ }^{11} \mathrm{C}$-raclopride in combination with PET to study the effect of a range of PCP doses on synaptic DA. In addition, we examined the effects of increased GABAergic inhibition on this response. Finally, we used ${ }^{11} \mathrm{C}$-cocaine to define more accurately contributions of DAT blockade to the possible DA-enhancing effects of PCP.

\section{MATERIALS AND METHODS}

\section{Baboon PET Studies}

Adult female baboons (Papio anubis, 14.5-18 kg) were prepared for PET scanning as detailed previously (Dewey et al, 1992). Animals were initially immobilized with Saffan $(\sim 10 \mathrm{ml})$ and subsequently maintained on gas anesthesia using isoflurane, nitrous oxide, and oxygen for the duration of the PET study. ${ }^{11} \mathrm{C}$-raclopride was synthesized as previously described (specific activity, $500-900 \mathrm{mCi} / \mu \mathrm{mol}$ ). In all studies, dynamic PET scanning commenced simultaneously with ${ }^{11} \mathrm{C}$-raclopride injection and was performed for $60 \mathrm{~min}$ in a Siemens HR + using the following scanning protocol: 10 scans with a 1-min interval followed by 10 scans with a 5-min interval. For ${ }^{11} \mathrm{C}$-cocaine (synthesized according to Fowler et al, 1989), the scanning protocol was four scans with a 0.5 -min interval followed by four scans with a 1.0 -min interval, four scans with a 2.0 -min interval, four scans with a 5.0-min interval, and four scans with a 7.0min interval.
Arterial blood was sampled continuously for the first 2 min using an automated device (Ole Dich, Hvidovre, Denmark) and then manually at 5.0, 10.0, 30.0, and $60.0 \mathrm{~min}$ postinjection. Selected plasma samples $(1.0,5.0,10.0$, and 30.0 min postinjection) were analyzed for the presence of unchanged radiotracer.

\section{Pharmacologic Treatment Strategy}

In the first series of studies, phencyclidine hydrochloride (PCP, Sigma Pharmaceuticals) was administered as an intravenous bolus injection at $0.1,0.5$, and $1.0 \mathrm{mg} / \mathrm{kg} 30 \mathrm{~min}$ prior to the second ${ }^{11} \mathrm{C}$-raclopride scan. To potentiate whole-brain GABAergic transmission, $\gamma$-vinyl GABA (GVG, a specific suicide inhibitor of GABA amino-transferase, GABA-T; Jung et al, 1977) was administered $2.5 \mathrm{~h}$ prior to PCP administration. The inhibition of GABA-T has been shown to elevate GABA concentrations significantly in the human CNS, maximally between 2 and $4 \mathrm{~h}$ following parenteral administration (Palfreyman et al, 1981).

In the next series of studies, animals received a baseline ${ }^{11} \mathrm{C}$-cocaine scan followed by PCP $(0.5$ and $1.0 \mathrm{mg} / \mathrm{kg})$ given $30 \mathrm{~min}$ prior to or coadministered with the second ${ }^{11} \mathrm{C}$ cocaine injection. For the coadministration studies, a solution of PCP was prepared prior to the second radiotracer delivery and injected into the vial containing the ${ }^{11} \mathrm{C}$ cocaine, immediately prior to intravenous injection and subsequent scanning.

\section{Design of Studies}

All scanning protocols involved two ${ }^{11} \mathrm{C}$-raclopride or ${ }^{11} \mathrm{C}$ cocaine injections, while each animal remained in the tomograph. The first scan served as the baseline for the second, postchallenge scan.

We previously established the reproducibility of ${ }^{11} \mathrm{C}$ raclopride binding as well as the effects of GVG on this binding in papio anubis baboons, using a test/retest experimental protocol in which each animal $(n=7)$ served as its own control (Dewey et al, 1992). PCP was administered $30 \mathrm{~min}$ prior to the second ${ }^{11} \mathrm{C}$-raclopride scan, according to a time course established by Blin et al (1991). These studies were performed using $0.1 \mathrm{mg} / \mathrm{kg}$ $(n=1), 0.5 \mathrm{mg} / \mathrm{kg}(n=6)$, and $1.0 \mathrm{mg} / \mathrm{kg}(n=3)$ PCP. In a separate group of animals, GVG was administered intravenously $(300 \mathrm{mg} / \mathrm{kg}$ in $4.0 \mathrm{ml}$ over $3 \mathrm{~min}$ ) immediately following completion of the first dynamic scan $(n=4)$. After $2.5 \mathrm{~h}$, PCP was administered $30 \mathrm{~min}$ prior to the second ${ }^{11} \mathrm{C}$-raclopride scan.

Finally, we examined the time course and effects of PCP on ${ }^{11} \mathrm{C}$-cocaine binding by administering PCP $(1.0 \mathrm{mg} / \mathrm{kg})$ either $30 \mathrm{~min}$ prior to the second ${ }^{11} \mathrm{C}$-cocaine scan or simultaneously ( 0.5 or $1.0 \mathrm{mg} / \mathrm{kg})$ with ${ }^{11} \mathrm{C}$-cocaine.

\section{Region of Interest Selection}

Regions of interest (ROI) for the corpus striatum were drawn directly on the PET image to encompass the entire structure on every slice upon which it appeared and where appropriate in size for the resolution of the tomograph. This multiplanar method of ROI selection reduces differences that may arise due to movement of the animal within the 
gantry during the scanning interval (Dewey et al, 1990). ROIs were then copied directly from the first scan to the appropriate slices of the second. Further analysis was targeted at separating the dorsal and ventral striata according to methods described by Drevets et al (1999). Cerebellar ROIs were drawn at the level of the vermis and included both cortical gray and white matter.

\section{Data Analysis}

Receptor availability as a function of changes in endogenous DA concentration was analyzed using a graphical technique specifically designed for reversible systems. This technique gives a linear function of the free receptor concentration known as the distribution volume (DV; Logan et al, 1990). The ratio of striatal to cerebellar distribution volumes (DVR) is less sensitive to noise than the individual kinetic parameters, which often have large standard errors associated with their determination. In addition, the DVR is independent of blood flow, since blood flow terms appear in the numerator and denominator and subsequently cancel out $\left(K_{1} / k_{2}\right.$; Logan et al, 1994). The use of the DVR is also supported by the observations that the striatum and cerebellum have comparable amounts of nonspecific binding (Farde et al, 1989) and that our preliminary studies demonstrated that PCP did not alter the cerebellar DV in a systematic manner (either increase or decrease) in excess of the test-retest variability for this region.

We quantified ${ }^{11} \mathrm{C}$-cocaine binding using a similar tracer kinetic modeling approach applied to differences in the availability of striatal transport proteins between test/retest animals or those pretreated with PCP. One factor that might affect estimates of binding site densities based on PET measurements is variability in the local concentration of $\mathrm{DA}$; however, recent studies have demonstrated that ${ }^{11} \mathrm{C}$ cocaine is relatively insensitive to changes in endogenous DA (Gatley et al, 1995), consistent with in vitro competition experiments with DA, suggesting that cocaine binds about 100 times more strongly at the DAT than DA (Madras et al, 1989). However, both ${ }^{11} \mathrm{C}$-raclopride and ${ }^{11} \mathrm{C}$-cocaine possess a rapid dissociation constant (Logan et al, 1990). This facilitates a similar fundamental kinetic modeling approach, so as with ${ }^{11} \mathrm{C}$-raclopride, DVRs for striatum and cerebellum can be related to the ${ }^{11} \mathrm{C}$-cocaine-binding site kinetic parameters by the ratio of striatal to cerebellar DVs.

\section{Statistical Analysis}

The statistical analysis was designed to test whether there was a difference in radiotracer binding between the dorsal and ventral tiers of the striatum and then whether this difference was a function of drug treatment prior to the second scan. Thus, differences between dorsal and ventral striata were evaluated with a one-way analysis of variance (ANOVA) across baseline scans and both baseline and challenge data were then subjected to a two-way repeated measures ANOVA with treatment group and region (dorsal $v s$ ventral) as factors. Where appropriate, post hoc significance testing was performed with a Bonferroni $t$-test. Finally, to reduce the number of comparisons and to take into account the baseline condition, difference scores were computed for the striatum, cerebellum, and the striatum to cerebellum ratio, using the formula $\left(\mathrm{DVR}_{\text {Baseline }}\right.$ scan $\mathrm{DVR}_{\text {Challenge }}$ scan $/ \mathrm{DVR}_{\text {Baseline scan. The difference scores }}$ were subjected to a one-way ANOVA, with treatment group as a between-subject factor. The mean time-activity of ${ }^{11} \mathrm{C}$-raclopride (corrected for the injected dose) was also subjected to a repeated measures ANOVA to address specific changes in radiotracer washout between animals.

\section{RESULTS}

\section{${ }^{11}$ C-Raclopride PET Scans}

Immediately following administration of ${ }^{11} \mathrm{C}$-raclopride, radioactivity accumulated in the corpus striatum bilaterally. In the cerebellum, radioactivity began to clear within the first $3 \mathrm{~min}$ and reached $50 \%$ of the peak within $5 \mathrm{~min}$. Striatal radioactivity continued to accumulate and reached a peak value within $5 \mathrm{~min}$ and cleared to $50 \%$ of the peak within $25 \mathrm{~min}$. In terms of the DVR, the test/retest reproducibility was determined to be $2.6 \%$ from the first to the second ${ }^{11} \mathrm{C}$-raclopride scan (Table 1; test/retest reliability derived from $\mathrm{DVR}_{\text {Baseline }}$ and $\mathrm{DVR}_{\text {Challenge; }}$ $3.31 \pm 0.21$ and $3.24 \pm 0.23$, respectively; $t=1.023$, $p=0.325)$.

${ }^{11} \mathrm{C}$-raclopride DVR in all baseline scans was slightly, although not significantly, lower in the dorsal $v s$ ventral striatum $(n=18, \mathrm{DVR} \pm \mathrm{SEM}=3.19 \pm 0.09$ vs $3.44 \pm 0.1$, respectively; $\left.\mathrm{F}_{[1,34]}=3.707, p=0.063\right)$. There was no significant interaction between treatment group and region, such that PCP treatment did not selectively influence ${ }^{11} \mathrm{C}$ raclopride binding in the dorsal or ventral striatum $\left(\mathrm{F}_{[1,4]}=0.472, p=0.756\right)$, although there was a significant interaction between treatment group and scan when both regions were combined $\left(\mathrm{F}_{[1,4]}=7.979, p=0.002\right)$. Detailed analysis of this effect indicated a significant decline in ${ }^{11} \mathrm{C}$ raclopride binding from baseline to postchallenge in animals treated with $0.5 \mathrm{mg} / \mathrm{kg}$ PCP $\left(D^{2} R_{\text {Baseline }}\right.$ and $\mathrm{DVR}_{\text {Challenge }}=3.52 \pm 0.09$ and $3.00 \pm 0.12$, respectively; $t=8.80, p<0.001)$ and $1.0 \mathrm{mg} / \mathrm{kg}$ PCP $\left(\mathrm{DVR}_{\text {Baseline }}\right.$ and $\mathrm{DVR}_{\text {Challenge }}=3.14 \pm 0.15$ and $2.88 \pm 0.16$, respectively; $t=3.033, p<0.01)$. These decreases appeared to be greater in the ventral compared to the dorsal striatum. There were no significant differences in ${ }^{11} \mathrm{C}$-raclopride binding from baseline to challenge scans when animals were given the lowest dose of PCP $\left(0.1 \mathrm{mg} / \mathrm{kg} ; \quad D^{2} R_{\text {Baseline }}\right.$ and $\mathrm{DVR}_{\text {Challenge }}=3.65$ and 3.57 , respectively; $t=0.546$, $p=0.594)$ or $\mathrm{GVG}$ prior to $0.5 \mathrm{mg} / \mathrm{kg}$ PCP $\left(\mathrm{DVR}_{\text {Baseline }}\right.$ and $\mathrm{DVR}_{\text {Challenge }}=3.25 \pm 0.29$ and $3.14 \pm 0.21$, respectively; $t=1.501, p=0.157)$. None of the doses of PCP or GVG prior to PCP altered cerebellar radioactivity, the systemic rate of labeled raclopride metabolism, or the metabolite corrected plasma input function. Figure 1 illustrates the graphical analysis applied to data from two separate animals, one given PCP alone (Figure 1a) and the other pretreated with GVG and PCP (Figure 1b).

Figures 2 and 3 demonstrate the temporal binding parameters of ${ }^{11} \mathrm{C}$-raclopride. We observed significant differences across time points between the baseline and postchallenge scans in the group given PCP alone (Figure 2), but not in the group pretreated with GVG and then PCP (Figure 3). In primates who received only PCP, a repeated 
Table I Percent Change in the Striatal DVR of " C-Raclopride or "C-Cocaine Produced by PCP or a Combination of PCP and the GABA-T Inhibitor, GVG

\begin{tabular}{lccc}
\hline & \multicolumn{2}{c}{ Mean \% change in DVR \pm SEM } \\
\cline { 2 - 4 } Group & Dorsal & Ventral & Both \\
\hline${ }^{\prime \prime}$ C-raclopride & & & \\
Test/retest ${ }^{\prime \prime} C$-raclopride $(n=4)$ & $-4.13 \pm 3.93$ & $-2.97 \pm 1.38$ & $-2.26 \pm 3.89$ \\
GVG $(300 \mathrm{mg} / \mathrm{kg} ; n=6)$ & $7.06 \pm 1.48^{\dagger}$ & $9.41 \pm 3.45^{\dagger}$ & $19.01 \pm 2.2^{\dagger}$ \\
PCP $(0.1 \mathrm{mg} / \mathrm{kg} ; n=1)$ & -1.07 & -2.2 & -2.19 \\
PCP $(0.5 \mathrm{mg} / \mathrm{kg} ; n=6)$ & $-13.49 \pm 1.82$ & $-15.13 \pm 2.69^{\dagger}$ & $-14.96 \pm 2.21^{\dagger}$ \\
PCP $(1.0 \mathrm{mg} / \mathrm{kg} ; n=3)$ & $-5.43 \pm 1.8$ & $-9.78 \pm 1.07$ & $-8.18 \pm 1.12$ \\
GVG $(300 \mathrm{mg} / \mathrm{kg})+P C P(0.5 \mathrm{mg} / \mathrm{kg} ; n=4)$ & $-1.43 \pm 5.75^{\dagger}$ & $-3.86 \pm 3.02^{\ddagger}$ & $-3.38 \pm 3.13^{\ddagger}$ \\
& & & \\
${ }^{\prime \prime} C$-cocaine & & & $-0.49 \pm 4.65$ \\
Test/retest ${ }^{\prime \prime} \mathrm{C}$-cocaine $(n=3)$ & $1.01 \pm 4.69$ & $-1.29 \pm 5.03$ & $-9.59 \pm 5.78$ \\
PCP $(1.0 \mathrm{mg} / \mathrm{kg}) 30$ min prior $(n=2)$ & $-10.23 \pm 5.33$ & $-9.12 \pm 5.79$ & $-25.54 \pm 4.26^{\S}$ \\
PCP $(0.5 \mathrm{mg} / \mathrm{kg})$ coadministered $(n=3)$ & $-26.64 \pm 3.29^{\S}$ & $-24.71 \pm\left. 4.4\right|^{\S}$ & -13.52 \\
PCP $(1.0 \mathrm{mg} / \mathrm{kg})$ coadministered $(n=1)$ & -14.10 & -18.11 & \\
\hline
\end{tabular}

†Significantly different from " $\mathrm{C}$-raclopride test/retest, $p<0.05$.

¥Significantly different from ${ }^{~ I C} \mathrm{C}$-raclopride PCP $(0.5 \mathrm{mg} / \mathrm{kg}), p<0.05$

İSignificantly different from ${ }^{~ I I} \mathrm{C}$-raclopride PCP $(0.5 \mathrm{mg} / \mathrm{kg}), p<0.01$.

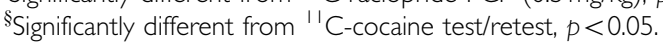
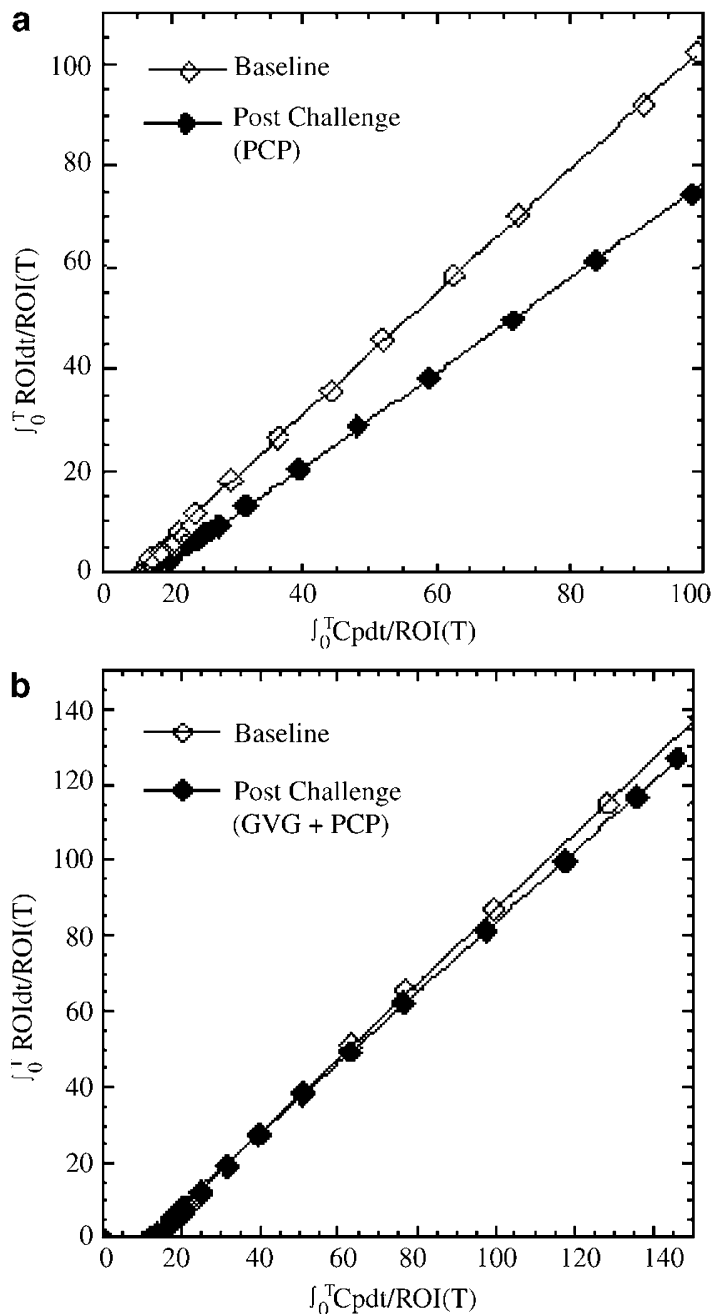

Figure I Graphical analysis of the ${ }^{1 /} \mathrm{C}$-raclopride time-activity data from striatal ROls in (a) one primate given a $0.5 \mathrm{mg} / \mathrm{kg}$ PCP challenge and (b) a primate pretreated with GVG $(300 \mathrm{mg} / \mathrm{kg}$ ) followed by the same PCP challenge. $\mathrm{ROI}(T)$ refers to radioactivity in the striatum at time $T . C_{p}(t)$ is the plasma radioactivity concentration corrected for metabolites.

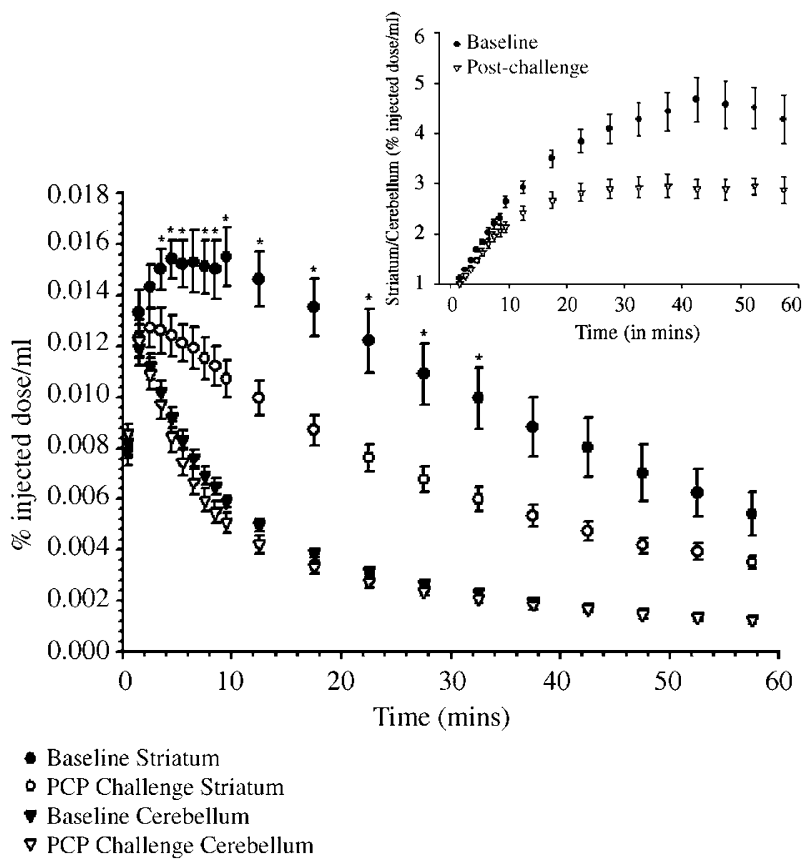

Figure 2 Time-activity data from striatum and cerebellum ROls from five PET studies where primates were given a PCP challenge $(0.5 \mathrm{mg} / \mathrm{kg})$ prior to the second " $\mathrm{C}$-raclopride scan. All points on the graph are corrected for the presence of labeled raclopride metabolites, and represent mean \pm standard error for all three animals. Univariate repeated measures ANOVA indicates a significant difference between baseline and postchallenge (PCP alone) conditions at a given time, $T\left({ }^{*} p<0.05\right)$.

measures ANOVA indicated that significant differences between baseline and postchallenge ${ }^{{ }^{11}} \mathrm{C}$-raclopride scans correlated with times of peak radioactivity (beginning 4.5 min after injection, $\mathrm{F}=20.79, p=0.049-27.5 \mathrm{~min}$ postinjection, $\mathrm{F}=18.48, p=0.0501)$. Further, only one baseline point in the GVG + PCP time-activity curve (Figure 3 ) appeared significantly different from a postchallenge point (occurring $7.5 \mathrm{~min}$ postinjection, $\mathrm{F}=8.50, p=0.0427$ ). Separate analysis of striatal and cerebellar values indicated 


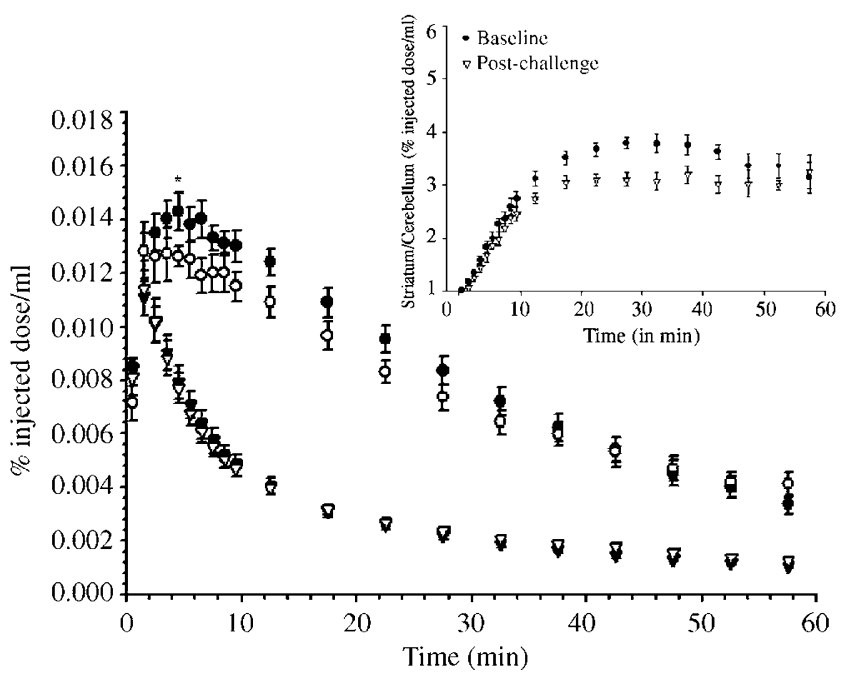

- Baseline Striatum

- GVG + PCP Striatum

- Baseline Cerebellum

$\checkmark \mathrm{GVG}+\mathrm{PCP}$ Cerebellum

Figure 3 Time-activity data from striatum and cerebellum ROls from four PET studies where primates were pretreated with GVG $(300 \mathrm{mg} / \mathrm{kg})$ prior to a PCP challenge $(0.5 \mathrm{mg} / \mathrm{kg})$ before the second " $\mathrm{C}$-raclopride scan. All points are corrected for the presence of labeled raclopride metabolites, and represent mean \pm standard error for all five animals. Univariate repeated measures ANOVA indicates a significant difference between baseline and postchallenge (GVG + PCP) conditions at a given time, $T(* p<0.05)$.

significant between-group differences in striatal activity from baseline to postchallenge $(\mathrm{F}=45.60, p<0.0001)$, but not in cerebellar activity $(\mathrm{F}=2.71, p=0.108)$.

\section{${ }^{11}$ C-Cocaine PET Scans}

There was a marked accumulation of ${ }^{11} \mathrm{C}$-cocaine in striatal regions, whereas levels of radioactivity in the cerebellum were much lower in all groups. Analysis of radioactivitycorrected time-activity curves indicates that the striatal accumulation of ${ }^{11} \mathrm{C}$-cocaine peaked around $5.0 \mathrm{~min}$, and rapidly declined. The test/retest reliability of ${ }^{11} \mathrm{C}$-cocaine is given in Table 1 . Regional analysis of all baseline ${ }^{11} \mathrm{C}$ cocaine specific binding in the dorsal $v s$ ventral striata indicated that there were no regional effects $(n=8$, $\mathrm{DVR} \pm \mathrm{SEM}=2.13 \pm 0.16$ vs $2.3 \pm 0.2$, respectively; $\left.\mathrm{F}_{[1,14]}=0.679, p=0.424\right)$. However, there appears to be a significant interaction between treatment group and DVR when the regions were combined, such that a significant reduction in ${ }^{11} \mathrm{C}$-cocaine binding depended on the PCP treatment regimen $\left(\mathrm{F}_{[3,4]}=9.94, p=0.025\right)$. Detailed analyses of interactions between PCP and DAT sites indicate a significant inhibition of ${ }^{11} \mathrm{C}$-cocaine binding only when coadministered with $0.5 \mathrm{mg} / \mathrm{kg}$ PCP $\quad\left(\mathrm{DVR}_{\text {Baseline }}\right.$ and $\mathrm{DVR}_{\text {Challenge }}=2.55 \pm 0.23$ and $1.90 \pm 0.28$, respectively; $t=6.830, p=0.002)$. At $1.0 \mathrm{mg} / \mathrm{kg}$ given $30 \mathrm{~min}$ prior to ${ }^{11} \mathrm{C}$-cocaine or coadministered, there were no significant effects (30 min pretreat: DVR Baseline and $\mathrm{DVR}_{\text {Challenge }}=1.83 \pm 0.10$ and $1.65 \pm 0.20$, respectively; $t=1.839, p=0.140$ and coadministered: $\mathrm{DVR}_{\text {Baseline }}$ and $\mathrm{DVR}_{\text {Challenge }}=2.44$ and 2.11 , respectively).

\section{DISCUSSION}

In the present study, we used PET to explore the hypothesis that targets outside the NMDA receptor complex contribute to PCP-induced decreases in ${ }^{11} \mathrm{C}$-raclopride binding. First, we provide evidence that GABAergic systems are involved in this response, since it can be attenuated with GVG pretreatment. Second, our data demonstrate a potent interaction between PCP and the ${ }^{11} \mathrm{C}$-cocaine-binding site in the living primate, which may contribute to decreases in striatal ${ }^{11} \mathrm{C}$-raclopride binding by preventing reuptake of synaptic DA, in addition to blocking norepinephrine and serotonin reuptake. Together, these experiments contribute to a growing body of literature suggesting that NMDA antagonist mediated changes in striatal DA may be partially mediated by GABAergic systems, and also by blockade of monoamine transporters.

PET studies in humans demonstrated that ketamine significantly reduced the binding of ${ }^{11} \mathrm{C}$-raclopride, consistent with increased competition from synaptic DA (Breier et al, 1998; Smith et al, 1998; Vollenweider et al, 2000). However, recent microdialysis findings suggest that PCP may not increase striatal ECF DA in nonhuman primates (Adams et al, 2002), and that ketamine may not alter ${ }^{11} \mathrm{C}$ raclopride binding in humans (Kegeles et al, 2002). Studies by Tsukada et al (2000) may present some resolution to this problem. They combined microdialysis and PET measures in conscious monkeys to demonstrate that ketamine decreased ${ }^{11} \mathrm{C}$-raclopride binding, but did not affect extracellular DA. Further, Tsukada et al (2001) attribute ketamine's lack of effect on extracellular systems to an increased efficacy of DAT sites, while our data suggest that PCP specifically, is a more potent blocker of these proteins than was previously thought. Thus, microdialysis measures of increases in extracellular DA in response to PCP might reflect spillover secondary to monoamine transporter blockade at higher doses (Schiffer et al, 2001a), while lower doses of PCP may be absent from this effect. In fact, recent findings using MK-801 have provided evidence that this drug increases the availability of DAT sites (Nakano et al, 1998; Page et al, 2000; Schiffer et al, 2001b; Kagawa et al, 2002). Taken together, it appears that individual NMDA antagonists might produce compound-specific effects on striatal dopaminergic systems as a function of their affinity for targets outside the NMDA receptor complex. In agreement with this, recent in vitro data also suggest that ketamine and to a lesser extent PCP, compete directly with ${ }^{3} \mathrm{H}$-raclopride binding at the high affinity $\mathrm{D}_{2}$ receptor site (Kapur and Seeman, 2001, 2002). Therefore, it appears that there may be a multitude of mechanisms by which PCP increases extracellular DA or alters ${ }^{11} \mathrm{C}$-raclopride binding.

If NMDA receptor antagonism diminishes GABA neuron firing (Hondo et al, 1995), then systemically increasing GABAergic inhibition (via $\mathrm{GABA}_{\mathrm{A}}$ or $\mathrm{GABA}_{\mathrm{B}}$ receptor agonists) should have little consequence. In fact, our previous in vivo microdialysis results in freely moving animals demonstrated that increased GABAergic activity produced a preferential inhibition of cortical over subcortical DA release (Schiffer et al, 2001a). Similarly, local application of specific GABA receptor agonists (muscimol, baclofen, or bicuculline) in cortical (Yonezawa et al, 1998) or subcortical (Westerink et al, 1996) areas produced a 
similar inhibition of the same system. Consistent with these studies, electrophysiological measures in the hippocampus suggest that disinhibition of GABAergic regulatory processes by NMDA antagonists may be a primary mechanism associated with NMDA antagonist-induced stimulation (Grunze et al, 1996). Combined with behavioral evidence indicating that GVG and other GABA agonists can diminish some of the stereotypies associated with PCP (Seiler and Grauffel, 1992), it appears that at least some, if not all, of the GABAergic inhibitory control is spared from the effects of NMDA receptor antagonism.

It is possible that these 'spared' GABAergic effects are also a function of the dose of PCP, and may be related to its additional molecular targets. We demonstrate a significant, reproducible decrease in ${ }^{11} \mathrm{C}$-cocaine binding, consistent with direct competition for the DAT and perhaps a shared mechanism. Interestingly, this effect was less pronounced at the highest and lowest doses of PCP. This provides one explanation for previous findings in which doses below those used here did not increase striatal extracellular DA, nor did they markedly influence nomifensine-induced DA overflow (Adams et al, 2002). The present PET studies suggest an inverted U-shaped dose-response curve for both inhibiting ${ }^{11} \mathrm{C}$-raclopride and ${ }^{11} \mathrm{C}$-cocaine binding, where $0.5 \mathrm{mg} / \mathrm{kg}$ PCP produced a greater inhibition of both radiotracers than $1.0 \mathrm{mg} / \mathrm{kg}$. Thus, doses of $1.0 \mathrm{mg} / \mathrm{kg}$ PCP may exceed the psychotomimetic and addictive effects of PCP, and our results at these doses represent those that might occur during anesthesia or during preanesthetic ataxic states associated with PCP. Consistent with this latter hypothesis, we did not have to alter our anesthesia at any time following PCP administration and there were no changes in vital signs following its administration.

Direct competition with transporter proteins does not completely explain the present finding that increasing GABAergic tone attenuates PCP-induced decreases in ${ }^{11} \mathrm{C}$ raclopride binding. For example, in the present study, while GVG attenuated PCP-induced decreases in ${ }^{11} \mathrm{C}$-raclopride binding, it totally abolished cocaine-induced decreases in ${ }^{11}$ C-raclopride binding (Dewey et al, 1998). However, effects reported with cocaine may also involve other neurotransmitter systems including serotonin, acetylcholine, and norepinephrine. Consistent with this notion of multitransmitter effects, a component of the PCP-induced effects may be related to NMDA receptor modulation. In fact, comparisons of PCP and MK-801, which have little or no affinity for the DAT (Maurice et al, 1991), indicate that both drugs possess rewarding and reinforcing properties (Willins, 1993), even though there is little support for an excitatory effect of MK-801 on DA activity (Mele et al, 1998). Further, if the present reductions in ${ }^{11} \mathrm{C}$-raclopride binding were due to a direct competition for $\mathrm{D}_{2}$ receptor sites (Kapur and Seeman, 2001, 2002), then it is unlikely that a priori increases in GABAergic tone would influence this effect. Thus, it appears that PCP-induced decreases in ${ }^{11} \mathrm{C}$ raclopride binding are related to a combination of direct stimulation from glutamatergic spillover (Adams and Moghaddam, 1998) and DAT blockade itself (Schiffer et al, 2001a) and that like cocaine, these decreases are susceptible to partial modulation by GABAergic systems.

Finally, these studies continue to support our premise that moderate affinity radiotracers provide a dynamic measure of competition from synaptic DA, which appear sensitive to pharmacologic manipulations of dopaminergic, serotonergic, GABAergic, cholinergic, and now glutamatergic systems (Dewey et al, 1993b, 1995; Schloesser et al, 1996). PET therefore provides a unique opportunity to observe and compare the cascade of neurochemical events produced by drugs that appear to have similar initial targets. These data may have implications for the development of unique therapeutic strategies targeted at specific neurotransmitter systems currently implicated in schizophrenia and addiction.

\section{ACKNOWLEDGEMENTS}

We gratefully acknowledge J Fowler, P Vaska, D Alexoff, D Schlyer, P King, P Carter, N Pappas, M Gerasimov, C Shea, $\mathrm{V}$ Garza, and $\mathrm{R}$ Ferrieri. Hoescht Marion Roussel and ChiroTech supplied the GVG. This research was carried out at Brookhaven National Laboratory under contract with the US Department of Energy Office of Biological and Environmental Research (USDOE/OBER DE-AC02-98CH10886), and partially funded by NIH awards to WKS (F31DA15874) and SLD (DA015041).

\section{REFERENCES}

Adams B, Moghaddam B (1998). Corticolimbic dopamine neurotransmission is temporally dissociated from the cognitive and locomotor effects of phencyclidine. J Neurosci 18: 5545-5554.

Adams BW, Bradberry CW, Moghaddam B (2002). NMDA antagonist effects on striatal dopamine release: microdialysis studies in awake monkeys. Synapse 43: 12-18.

Blin J, Denis A, Yamaguchi T, Crouzel C, MacKenzie ET, Baron JC (1991). PET studies of [18F]methyl-MK-801, a potential NMDA receptor complex radioligand. Neurosci Lett 121: 183-186.

Breier A, Adler CM, Weisenfeld N, Su TP, Elman I, Picken L et al (1998). Effects of NMDA antagonism on striatal dopamine release in healthy subjects: application of a novel PET approach. Synapse 29: 142-147.

Carlezon WA, Wise RA (1996). Rewarding actions of phencyclidine and related drugs in nucleus accumbens shell and frontal cortex. J Neurosci 16: 3112-3122.

Dewey SL, Brodie JD, Fowler JS, MacGregor RR, Schlyer DJ, King PT et al (1990). Positron emission tomography (PET) studies of dopaminergic/cholinergic interactions in the baboon brain. Synapse 6: 321-327.

Dewey SL, Morgan AE, Ashby Jr CR, Horan B, Kushner SA, Logan $J$ et al (1998). A novel strategy for the treatment of cocaine addiction. Synapse 30: 119-129.

Dewey SL, Smith GS, Logan J, Alexoff D, Ding YS, King P et al (1995). Serotonergic modulation of striatal dopamine measured with positron emission tomography (PET) and in vivo microdialysis. J Neurosci 15: 821-829.

Dewey SL, Smith GS, Logan J, Brodie JD (1993a). Modulation of central cholinergic activity by GABA and serotonin: PET studies with 11C-benztropine in primates. Neuropsychopharmacology 8: 371-376.

Dewey SL, Smith GS, Logan J, Brodie JD, Simkowitz P, MacGregor $\mathrm{RR}$ et al (1993b). Effects of central cholinergic blockade on striatal dopamine release measured with positron emission tomography in normal human subjects. Proc Natl Acad Sci USA 90: 11816-11820.

Dewey SL, Smith GS, Logan J, Brodie JD, Yu DW, Ferrieri RA et al (1992). GABAergic inhibition of endogenous dopamine release 
measured in vivo with 11C-raclopride and positron emission tomography. J Neurosci 12: 3773-3780.

Drevets WC, Price JC, Kupfer DJ, Kinahan PE, Lopresti B, Holt D et al (1999). PET measures of amphetamine-induced dopamine release in ventral $v s$ dorsal striatum. Neuropsychopharmacology 21: 694-709.

Farde L, Eriksson L, Blomquist G, Halldin C (1989). Kinetic analysis of central [11C]raclopride binding to D2-dopamine receptors studied by PET-a comparison to the equilibrium analysis. J Cereb Blood Flow Metab 9: 696-708.

Fowler JS, Volkow ND, Wolf AP, Dewey SL, Schlyer DJ, Macgregor RR et al (1989). Mapping cocaine binding sites in human and baboon brain in vivo. Synapse 4: 371-377.

Gatley SJ, Volkow ND, Fowler JS, Dewey SL, Logan J (1995). Sensitivity of striatal [11C]cocaine binding to decreases in synaptic dopamine. Synapse 20: 137-144.

Grunze HC, Rainnie DG, Hasselmo ME, Barkai E, Hearn EF, McCarley RW et al (1996). NMDA-dependent modulation of CA1 local circuit inhibition. J Neurosci 16: 2034-2043.

Hondo H, Nakahara T, Nakamura K, Hirano M, Uchimura H, Tashiro N (1995). The effect of phencyclidine on the basal and high potassium evoked extracellular GABA levels in the striatum of freely moving rats: an in vivo microdialysis study. Brain Res 671: 54-62.

Johnson KM, Snell LD (1985). Effects of phencyclidine (PCP)-like drugs on turning behavior, $3 \mathrm{H}$-dopamine uptake, and $3 \mathrm{H}-\mathrm{PCP}$ binding. Pharmacol Biochem Behav 22: 731-735.

Jung MJ, Lippert B, Metcalf BW, Bohlen P, Schechter PJ (1977). gamma-Vinyl GABA (4-amino-hex-5-enoic acid), a new selective irreversible inhibitor of GABA-T: effects on brain GABA metabolism in mice. $J$ Neurochem 29: 797-802.

Kagawa S, Nakano T, Inoue O, Nishimura T (2002). Effect of glutamatergic systems on in vivo binding of [(125)I]beta-CIT in the brain of a rat model of Parkinson's disease. Synapse 46: 38-44.

Kapur S, Seeman P (2001). Ketamine has equal affinity for NMDA receptors and the high-affinity state of the dopamine D2 receptor. Biol Psychiatry 49: 954-957.

Kapur S, Seeman P (2002). NMDA receptor antagonists ketamine and PCP have direct effects on the dopamine $\mathrm{D}(2)$ and serotonin 5-HT(2)receptors-implications for models of schizophrenia. Mol Psychiatry 7: 837-844.

Kegeles LS, Martinez D, Kochan LD, Hwang DR, Huang Y, Mawlawi $\mathrm{O}$ et al (2002). NMDA antagonist effects on striatal dopamine release: positron emission tomography studies in humans. Synapse 43: 19-29.

Li Q, Clark S, Lewis DV, Wilson WA (2002). NMDA receptor antagonists disinhibit rat posterior cingulate and retrosplenial cortices: a potential mechanism of neurotoxicity. J Neurosci 22: 3070-3080.

Logan J, Fowler JS, Volkow ND, Wolf AP, Dewey SL, Schlyer DJ et al (1990). Graphical analysis of reversible radioligand binding from time-activity measurements applied to [ $\mathrm{N}-11 \mathrm{C}$-methyl](-)-cocaine PET studies in human subjects. J Cereb Blood Flow Metab 10: 740-747.

Logan J, Volkow ND, Fowler JS, Wang GJ, Dewey SL, MacGregor R et al (1994). Effects of blood flow on [11C]raclopride binding in the brain: model simulations and kinetic analysis of PET data. $J$ Cereb Blood Flow Metab 14: 995-1010.

Madras BK, Fahey MA, Bergman J, Canfield DR, Spealman RD (1989). Effects of cocaine and related drugs in nonhuman primates. I. $[3 \mathrm{H}]$ cocaine binding sites in caudate-putamen. $J$ Pharmacol Exp Ther 251: 131-141.

Maurice T, Vignon J, Kamenka JM, Chicheportiche R (1991). Differential interaction of phencyclidine-like drugs with the dopamine uptake complex in vivo. J Neurochem 56: 553-559.

Mele A, Wozniak KM, Hall FS, Pert A (1998). The role of striatal dopaminergic mechanisms in rotational behavior induced by phencyclidine and phencyclidine-like drugs. Psychopharmacology 135: 107-118.

Nakano T, Takatoku K, Matoba Y, Iwamoto B, Nishiura M, Inoue O et al (1998). Enhancement of in vivo binding of [123I]beta-CIT by MK-801 in rat brain. Synapse 30: 402-408.

Olney JW, Farber NB (1995). Glutamate receptor dysfunction and schizophrenia. Arch Gen Psychiatry 52: 998-1007.

Page G, Peeters M, Maloteaux JM, Hermans E (2000). Increased dopamine uptake in striatal synaptosomes after treatment of rats with amantadine. Eur J Pharmacol 403: 75-80.

Palfreyman MG, Schechter PJ, Buckett WR, Tell GP, Koch-Weser J (1981). The pharmacology of GABA-transaminase inhibitors. Biochem Pharmacol 30: 817-824.

Rodefer JS, Carroll ME (1999). Concurrent progressive-ratio schedules to compare reinforcing effectiveness of different phencyclidine (PCP) concentrations in rhesus monkeys. Psychopharmacology (Berl) 144: 163-174.

Schiffer WK, Gerasimov M, Hofmann L, Marsteller D, Ashby CR, Brodie JD et al (2001a). Gamma vinyl-GABA differentially modulates NMDA antagonist-induced increases in mesocortical vs mesolimbic DA transmission. Neuropsychopharmacology 25: 704-712.

Schiffer WK, Gerasimov MR, Fowler JS, Volkow ND, Gifford A, Ashby CR et al (2001b). MK-801 increases dopamine transporter (DAT) availability: a positron emission tomography (PET) investigation in non-human primates. J Nucl Med 42: 56.

Schloesser R, Simkowitz P, Bartlett EJ, Wolkin A, Smith GS, Dewey SL et al (1996). The study of neurotransmitter interactions using positron emission tomography and functional coupling. Clin Neuropharmacol 19: 371-389.

Seiler N, Grauffel C (1992). Antagonism of phencyclidine-induced hyperactivity in mice by elevated brain GABA concentrations. Pharmacol Biochem Behav 41: 603-606.

Smith GS, Schloesser R, Brodie JD, Dewey SL, Logan J, Vitkun SA et al (1998). Glutamate modulation of dopamine measured in vivo with positron emission tomography (PET) and 11Craclopride in normal human subjects. Neuropsychopharmacology 18: 18-25.

Tsukada H, Harada N, Nishiyama S, Ohba H, Sato K, Fukumoto D et al (2000). Ketamine decreased striatal [(11)C]raclopride binding with no alterations in static dopamine concentrations in the striatal extracellular fluid in the monkey brain: multiparametric PET studies combined with microdialysis analysis. Synapse 37: 95-103.

Tsukada H, Nishiyama S, Kakiuchi T, Ohba H, Sato K, Harada N (2001). Ketamine alters the availability of striatal dopamine transporter as measured by [(11)C]beta-CFT and [(11)C]betaCIT-FE in the monkey brain. Synapse 42: 273-280.

Volkow ND, Wang GJ, Fowler JS, Logan J, Gatley SJ, Wong C et al (1999). Reinforcing effects of psychostimulants in humans are associated with increases in brain dopamine and occupancy of D(2) receptors. J Pharmacol Exp Ther 291: 409-415.

Vollenweider FX, Vontobel P, Oye I, Hell D, Leenders KL (2000). Effects of (S)-ketamine on striatal dopamine: a [11C]raclopride PET study of a model psychosis in humans. J Psychiatr Res 34: 35-43.

Westerink BH, Kwint HF, deVries JB (1996). The pharmacology of mesolimbic dopamine neurons: a dual-probe microdialysis study in the ventral tegmental area and nucleus accumbens of the rat brain. J Neurosci 16: 2605-2611.

Willins D (1993). The role of dopamine and AMPA/ kainate receptors in the nucleus accumbens in the hypermotility response to MK-801. Pharmacol Biochem Behav 46: 881-887.

Yonezawa Y, Kuroki T, Kawahara T, Tashiro N, Uchimura H (1998). Involvement of gamma-aminobutyric acid neurotransmission in phencyclidine-induced dopamine release in the medial prefrontal cortex. Eur J Pharmacol 341: 45-56. 